\title{
THE IMPACT OF HOST-COUNTRY POLITICAL RISK ON MULTINATIONALS' POLITICAL STRATEGY DEVELOPMENT
}

\author{
Dorottya Sallai, University of Greenwich, D.Sallai@greenwich.ac.uk \\ Gerhard Schnyder, Loughborough University London, G.Schnyder@lboro.ac.uk \\ Academy of International Business, UK Chapter
}

Journal of International Business Studies (JIBS) and Journal of International Business Policy

(JIBP) Paper Development Workshop

24-27 April, 2019

\begin{abstract}
:
The paper investigates how high levels of political risk in a host market's institutional context influences MNE subsidiaries' corporate political activity (CPA) strategy. Existing studies have found that subsidiaries facing high-risk contexts prefer a non-engaged approach to CPA, by exercising "no exit' and 'no voice' strategies. Based on interviews with business leaders in post-socialist Hungary - a context characterised by high political risk - we present contradictory evidence. We find that subsidiaries - do not limit their strategic responses to non-engagement but use a variety of different engaged and non-engaged strategies to maintain their position in the high-risk host market, but these strategies differ from the traditional 'voice' strategies used in low-risk contexts. The paper identifies five different strategic choices: 1. Active responsiveness, 2. Passive responsiveness, 3. A nonresponsive strategy of 'dormancy', 4. Restructuring to avoid being 'bought up' or pushed out of the market and 5. Exit, when firms leave the country. We theorise about the determinants of non-market strategic choices in high-risk environments and suggest that existing theories need to be expanded by applying an institutional legitimacy perspective to political risk.
\end{abstract}

KEYWORDS: Business-government relationships; Political strategies; Non-market strategies; Political risk, corporate political activities (CPA) 


\section{INTRODUCTION}

Political risk is a widely investigated phenomenon in international business research, since government actions may have a negative impact on firm performance (Boddewyn, 2005). Indeed, political risk has been defined as the host government's interference with MNEs' foreign operations (Han et al 2018: 124), especially in the context of foreign direct investment (FDI). Political risks are the key determinant of FDI decisions (Spar, 2001) and yet there is a lack of empirical research about the role environmental and intra-firm pressures in firms' behaviour in politically risky contexts (John and Lawton, 2018).

While the management literature explores how firms estimate and manage risks, studies on corporate political activity (CPA) investigate strategies and tactics that facilitate political risk assessment and control for performance implications (John and Lawton, 2018; Lawton et al., 2013). The institutional literature on political risk and FDI decisions limit their focus on firms' market entry decisions (Delios and Henisz, 2003) and on their exit strategies, but ignore how firms manage political uncertainty when already in the market (John and Lawton, 2018).

Existing studies that explore how multinational firms react to high political risk identify three key strategies that firms use to manage host country's political risk: exit, organisational restructuring or non-engagement. Some studies conclude that when faced with high political risk, MNE subsidiaries either exit or do not even enter the host market (Meyer et al., 2009). Others claim that subsidiaries will chose and deploy a non-engaged approach to CPA (De Villa et al., 2018) whereby they exercise loyalty to the host market by staying or entering but will not actively engage in political strategies. A third approach claims that firms will aim to buffer the impact of high political risk, for instance the impact of informal political ties, by rearranging their organisational structure in order to segregate, isolate, hide and cut off political ties (Dieleman and Boddewyn 2012). Hence the extant literature seems to suggest that when faced with high political risk, especially in an emerging market context, subsidiaries will either chose not to engage with the host country's government or they will take a reactive stance and focus their strategies on limiting the damage that the high-risk environment might 
cause. Yet, our empirical study found that when faced with increased political risk, firms chose different strategies, some opt for engagement, while others for non-engagement. Hence the puzzle arises, what explains the discrepancy in our empirical findings? How can we explain that in some high-risk context firms opt for non-engagement, while in other, companies chose both engaged and non-engaged strategies in their political activities? Can we explain the different approaches with differences in the host country's institutional environment or are differences linked to other factors, such as political legitimacy or the nature of risk? What are the institutional determinants of engagement and non-engagement in international business? Existing literature has focused on how subsidiaries mitigate or avoid risk, but not on how firms manage or engage political risk once they are in a market and decide to stay in a specific host country environment (Lu at al., 2014). The question of what political strategies allow subsidiaries to remain or succeed in politically risky countries has not been fully answered (John and Lawton, 2018). We address earlier calls to focus on the combination of CPA choices and non-engaged political strategies in different locations and across time (De Villa et al., 2018).

The type of strategy that is effective may depend not only on firm-level factors, but also on the precise nature of political risk - which in turn is determined by institutional factors. Risk in a host country depends on the country's stage of institutional and economic development (Han et al., 2018). Hence MNEs in well-established socio-economic systems might face non-violent political risks, such as unfavourable legislation or stringent entry requirements (Bremmer, 2014), whereas in less established capitalist systems they might face more severe risks such as expropriations, the overthrown of political regimes or wars (Getz and Oetzel, 2009).

Previous studies explored how firms leverage their experience with political risk across borders (Oh and Oetzel, 2017), how multinationals respond to major disasters at the subsidiary level (Oh and Oetzel, 2011) and how managers of multinational enterprises manage risk in fragile and/or conflict-affected areas of operation (Oetzel and Miklian, 2017). 
In order to understand the impact of risk, we need to clarify the nature of political risk. Some risks are continuous - such as corruption (Cuervo-Cazurra, 2008) - and hence predictable for firms, while others such as natural or political disasters are "discontinuous" and hence unpredictable (Oetzel and Oh, 2014). Discontinuous political risk is difficult to assess, especially in countries in which institutional arrangements "fall short of providing adequate and predictable support for business transactions and instead allow governments to exercise volatile control over regulation, resources, information and the license to operate" (Darendeli and Hill, 2016: 70). In host contexts where political risk is continuous, firms may decide to choose a different political strategy than in environments, where risk is discontinuous, and the host country context is more uncertain. Hence, in our definition of discontinuous risk, we do not refer to vis-majors such as natural disasters or wars, but rather to a situation when political and economic changes introduced by the government create high levels of uncertainty and unpredictability for firms.

We know very little about how MNE subsidiaries manage their CPA in host country contexts, where the political context changes and turns from a low-risk to a high-risk environment within a few years. This question is especially pressing in today's global economy, when firms face high, discontinuous-type political risk in many well-established market economies, such as Brexit in the UK, Trump's industrial policy in the US or Orbán's illiberal state in the EU member state Hungary.

We argue that in order to explore how MNEs manage high political risk or the impact of increasing political risk for FDI we need to consider applying an institutional legitimacy perspective to political risk. We will investigate how FDI is affected by high political risk or discontinuous risk and address earlier calls for research to challenge the assumption that service industries are largely immune from political risk (Stevens et al., 2016). This is a critical issue, as service firms now undertake more than 60 percent of all FDI worldwide (Kolstad and Villanger, 2008). We address Stevens and colleagues' (2016) call to explore how subsidiaries manage their CPA through the action of legitimacy building. 
We focus on Hungary, where political risk has drastically increased for foreign MNEs in the last eight years and for some industries the country turned from a low political risk environment into a high-risk context. Existing studies on MNEs' cross-border CPA choices focus their empirical investigation on African (De Villa et al., 2018) or South-East Asian countries (Meznar and Nigh, 1995), but the impact of political risk on MNE subsidiary's CPA choices has been underexplored within the European Union context, in countries where political risk has increased with the change of political context.

This paper aims to fill this gap by investigating how MNE subsidiaries engage in CPA in the increasingly high-risk political context of Hungary. Hungary has recently been referred to as taking a U-turn politically (Kornai, 2012) and 'backsliding' economically (Greskovits, 2015). It is often referred to as an 'elected autocracy' (Agh, 2015) or 'authoritarian capitalism' (Sallai and Schnyder, 2018). As such Hungary provides an interesting high-risk host country context within the European Union, in which the behaviour of MNE subsidiaries can be investigated.

The paper is structured as follows: The next section reviews the relevance of political legitimacy on FDI, the impact of political risk on firms' CPA engagement, and then explores how firms manage political risk by engaging in corporate political activity (CPA). After presenting the methods, we present the empirical evidence from interviews with top-level managers in Hungary. A final section concludes.

\section{THEORETICAL BACKGROUND}

\subsection{Political legitimacy and FDI}

The impact of political risk on international business (IB) firms is generally explored through two different theoretical lenses: the Bargaining Power Approach (BPA), and the Legitimacy Based Approach (LBA). BPA explores the relationship between firms and the state from the perspective of the balance of bargaining power. According to this approach firm-host organisation bargaining is an ongoing resource interdependence relationship, whose outcomes depend on resources the two parties 
have or would like to have from each other (Brewer, 1992). Firms' bargaining power in the host country decreases over time as initial investment sinks in and the subsidiary's technological and managerial advantages erode vis-à-vis local firms (Stevens et al., 2016). MNEs' stronger organizational capabilities, management skills, and strategies give them a competitive advantage over local firms in the early stages of entering new markets (Jiang et al., 2015; Mutlu et al., 2015). However, these advantages may erode over time, because local rivals close the gap on MNEs both in technology and management knowledge through mutual learning processes (Mutlu et al., 2015). As MNEs power in bargaining decreases, their political risk increases (Boddewyn, 2005) because they are less and less able to control the impact of government policy on their operations. This is especially pertinent in the post-socialist or emerging market context, where governments are more prone to introduce unexpected policy changes.

In contrast, according to the Legitimacy Based Approach (LBA), the government constantly investigates the attributes and activities of foreign firms in the host country in order to check whether they are consistent with the government's economic, political and social goals (Henisz and Zelner, 2005). Governments may be tempted to alter policies and introduce legislation to their political advantage and to the detriment of foreign firms (Stevens et al., 2016). More political constraints on the government's ability to change existing policies can be associated with less political risk for firms (Stevens et al., 2016). In a stable and democratic environment, the larger amount of political checks and balances lead to greater constraints on government intervention over companies.

Firms become legitimate if their activities are in line with the values of their host market environment. However International Business (IB) firms often encounter challenges in securing legitimacy as there are no international legislation or supranational organisations that would protect their rights -subsidiaries' rights stem from national laws (Boddewyn et al., 1994).

As a result, the legitimacy of foreign firms from the perspective of host governments, will depend on their contributions to national goals such as employment or technological investment (Stevens et al., 2016). When there is a congruence between the government's goals and the activities 
of the foreign business the legitimacy of the subsidiary increases in the eyes of the government (Kostova and Zaheer, 1999), however if they are not serving the government's purposes they can easily become targets of hostile legislative changes (Sallai, 2013; Sallai and Schnyder, 2015). More authoritarian governments tend to be responsive to a smaller circle of elites than democratic governments that are accountable to a larger set of interest groups (Stevens et al., 2016). Consequently, a more authoritarian government has more leeway to intervene in those firms' operations that lack legitimacy. However, as firms may not be aware of their lack of legitimacy or the method of intervention, new policies or change of legislation could cause them unanticipated shock to their operations and performance (Stevens et all, 2016) and a greater political risk for these nonlegitimate firms.

Political interference in MNEs' operations may also trigger a negative impact on the government's own goals, such as economic growth generated as a result of inward FDI (Luo, 2001). The perceived political risk by MNEs depends on whether their business objectives are consistent with the government's long-term agendas (Stevens et al., 2015). Consequently companies whose activities are aligned with the government's long-term goals may perceive a lower degree of political risk compared to those whose activities are not aligned (Henisz and Zelner, 2005).

Subsidiaries can gain legitimacy by making government officials view their presence as necessary for the government's objectives. Creating new workplaces, hiring local workers to reduce unemployment or investing in local infrastructure could be ways through which a subsidiary supports the government's long-term goals. Governments evaluate the degree to which foreign subsidiaries' presence and actions are legitimate or not based on these actions (Marquis and Qian, 2014) and the judgements about companies legitimacy could have serious consequences for subsidiary's survival in the host country context (Bitektine, 2011). If a government views a firm or a certain group of firms as legitimate, it could signal its support by providing resources, favourable policies or tax incentives to those selected firms (Oliver and Holzinger, 2008), whereas if it views a firm as non-legitimate it could introduce unexpected policy changes, new regulations or taxes that may create disruption in the firm's 
sector or industry. Based on the discussion above the following question arises: What kind of CPA strategies MNE subsidiaries engage in high risk host country contexts? In the next section we explore this question and look at how IB firms can manage FDI-related political risk with their CPA activities.

\subsection{Managing political risk with CPA}

International firms may choose to engage or not to engage in a bargaining relationship with the host government. Depending on managerial choice firms decide to comply with changes, avoid them or chose circumvention to offset the impact of government policy on their operations (Boddewyn and Brewer, 1994). Compliance refers to the situation when firms comply with legislation, whereas avoidance and circumvention assume that these firms can operate independently

of governmental constraints and incentives. To hedge against unfavourable government policies, firms might choose circumvention through illegal activities or other non-bargaining forms of political response (Boddewyn and Brewer, 1994). If companies feel that the political risks are too high, they might decide to leave the host country and opt for an 'exit' strategy (Hirschman, 1970).

The literature identifies conflictual and partnership type of bargaining behaviour. In a conflictual context both the government and firms try to appropriate rents or gains from each other. The resource-based view of conflictual bargaining argues that governments will try to make gains from firms, whereas firms will try to mitigate these governmental gains or try to make gains at the expense of governments (Stevens et al., 2016). In contrast, the partnership type of bargaining behaviour is a more positive view of business-government interactions. Partnership with governments is more likely to generate legitimacy than avoidance, circumvention, and conflictual bargaining, because partnering conveys a positive message and viewed almost like an approval of what international firms are doing (Boddewyn and Brewer, 1994: 130).

However most recent studies argue that CPA choices and political strategies should be divided into broader categories: the engaged and non-engaged approaches to CPA (De Villa et al., 2018). Engaged approaches include CPA actions aimed at influencing the host country's public policy by engaging with the host government (A. J. Hillman and Hitt, 1999), while the non-engaged 
approaches to CPA aim to enable the MNE to avoid or conform to host country public policy by evading engagement with the host government (De Villa et al., 2018).

The key difference between the two approaches is that while in the engaged approach MNEs try to share or modify the host country's public policy context, in the non-engaged approach they comply the host country's public policy environment but do not try to shape or modify it (De Villa et al., 2018). According to De Villa et al., there are four non-engaged political strategies through which MNEs adapt to the public policy context actively, rather than by passively conforming to high risk: low visibility, rapid compliance, reconfiguration and anticipation.

Low visibility refers to a situation when MNEs minimize public visibility and risk exposure by not engaging with host governments in order to avoid being the target of discriminatory policies or expropriation. Rapid compliance describes a strategy when MNEs introduce high speed actions to obey rules, including actions like not engaging in corruption, paying just prices to suppliers or modifying the MNE's organisational structure to comply with public policy. When firms rely on the reconfiguration strategy, they rearrange the MNE's organisational structure for competitiveness, modify processes to sustain competitiveness, develop new ways to supply to restricted host markets or substituting imports in a host operation for local production to appear as a local value-adding MNE. The anticipation strategy is focused on the prediction of public policy in order to get the MNE a firstmover advantage and ways to gain social support to enhance the MNE's legitimacy. Actions in this strategy include monitoring the host country's policy context, anticipating possibilities to comply with upcoming policy changes, and monitoring host and home government relations (De Villa et al., 2018). All these strategies are referred to as non-engaged strategies.

However, some scholars found that firms in high political risk host country contexts will try to protect themselves from the adverse impact of political ties with government actors instead of exiting or non-engaging. The most relevant existing study about political risk in autocratic regimes is Dieleman and Boddewyn's (2012) study about corporate strategies in Suharto's Indonesia. They argue that firms may use their organisational structure to mitigate the potentially negative impact of political 
risk in the host country. They conclude that a compartmentalized business-group structure constitutes an effective organisational response - or a 'buffering strategy' - to an autocratic political environment (Dieleman \& Boddewyn 2012: 91).

Yet even these studies do not tell us that besides restructuring, what other type of CPA strategies subsidiaries may engage in if they chose to stay in a high-risk country (John and Lawton, 2018). We do not sufficiently understand how firms in emerging economies protect themselves from high political risks and what strategies they implement if they chose to engage rather than go for the non-engagement option. Previous studies have argued that when MNE senior managers perceive high host country political risk, they tend to choose a non-engaged approach to CPA by avoiding or actively adapting to the host country's changing policy contexts (De Villa et al., 2018). Yet, it is not clear what subsidiaries do if they perceive high political risk and choose to take an engaged approach to CPA. To fill this gap, this study shows that high political risk may also encourage firms to engage in political activities and adapt to increasingly authoritarian regimes.

\subsection{FDI-led growth in Hungary's dependent market economy}

Various authors have proposed characterisations and classifications of the type of capitalism that is emerging in post-socialist states. The so-called Visegrad countries (Poland, Czech Republic, Slovakia, and Hungary), had transformed their industrial structure - to a significant extent with the help of Western Multinational Companies (MNCs) (Orenstein 2013, Martin 2013, 2008,), therefore has been referred to as 'dependent market economies' (Noelke \& Vliegenthart 2009). Indeed, FDI inflow into the Visegrad countries has accelerated around the time of their accession to the European Union in 2004, especially from Western European countries and contributed substantially to the economic restructuring of these post-socialist states. The predominantly German, Dutch and Austrian capital turned the region's manufacturing into manufacturing miracles (Bohle and Greskovits 2012) between 2004 and 2008 .

However, during the financial crisis FDI inflows have become volatile and started to decline (Bohle, 2018). The problems caused by the financial crisis of 2008, deepened society's 
disillusionment and led to an aggressive political rhetoric against foreign capital in Hungary and to a lesser extend Poland. Expectations of FDI such as increased domestic competitiveness, substantial growth and economic convergence with the more developed Western European states of the EU did not materialise due to the 'inability of domestic firms to become partners of local MNC subsidiaries, and finally the generally low inclination of MNCs to rely on local firms' (Sass, 2017: 48).

Although since the political turn in 1989, Hungary was a front-runner in attracting FDI, after the financial crisis it has dramatically left the Western reform path and increasingly turned against foreign businesses. Since the election of the national-conservative Fidesz government under Viktor Orbán in 2010, the previously most investment friendly country in the Visegrad four has turned into a high-risk political environment, at least for some foreign businesses. The three consecutive Orbán governments used their majority in parliament to impose high taxes on selected FDI dominated sectors (Sass and Kalotay, 2012: 1) and engaged in an intensive political rhetoric against multinational capital.

The political speak has started to refer to 'good' and 'bad' FDI (Sass, 2017). 'Bad' FDI was increasingly viewed as aiming to replace domestic producers or service providers and repatriating profits - therefore not being beneficial for the country's economy - whereas FDI that resulted in creating new jobs, contributing to the country's exports and allow domestic companies to get engaged in global value chains as suppliers, became increasingly viewed by the Orbán government as 'good' FDI (Sass, 2017). This state-level change of attitude towards FDI had a direct impact on subsidiaries' political legitimacy in Hungary, as well as the level of political risk they are experiencing in different sectors.

Research shows that since 2010, the three consecutive Orbán Governments consistently supported export-oriented industries, such as car manufacturing, electronics production and shared service centres (Sass, 2017) and provided them with generous incentives. Incentives included smaller corporate tax rates, low labour costs, and other subsidies, in some cases worth up to 50 percent of investment (Byrne, 2016). 
These export-oriented manufacturing sectors - that are considered to be 'good' FDI by the state - enjoy substantially smaller corporate taxes than their domestic counterparts. According to Sass (2017: 53), in 2015 the German carmaker, Audi, 'did not pay any corporate tax', whereas 'Wizz Air, Suzuki, GE, Mercedes and Bosch paid 1-2 percent corporate tax only'. In 2017, the government lowered corporate tax rate to 9 percent - the lowest in the EU - benefitting large companies and incentivizing mostly midsized Hungarian and foreign-owned multinational companies with more than EUR $2 \mathrm{~m}$ in revenue (Byrne, 2016) to use Hungary as a tax heaven.

At the same time, the Orbán governments have taken a hostile stance toward 'bad' FDI (Sass, 2017) by introducing special taxes and other regulatory measures, such as nationalisations and targeted sectoral regulations in service-related sectors. Foreign companies that serve the domestic market such as banking, energy, retail trade, telecommunications, and water supply were targeted with special, often discriminatory measures and legislative changes (Sass and Kalotay, 2012). According to the Financial Times, the contrast in the experience of foreign manufacturers compared with serviceoriented investors "points to Hungary's drive to position itself as a low-cost manufacturing and logistics base in Germany’s economic hinterland" (Byrne, 2016: 1).

Hence, although it has created an overall anti-foreign rhetoric in the last eight years, the Orbán government seems to be partial in its anti-FDI stance. It does not seek to fundamentally alter the country's 'export-led growth model' that depends on FDI (Bohle, 2018) as it still strongly supports competition for new industrial investment (Bohle, 2018), even if only in export-related industries.

The state's drastically contrasting approach towards different sectors of the economy create a very interesting risk context in which IB firms behaviour can be investigated. According to earlier literature firms in targeted high risk industries would chose between three strategies: exit the Hungarian market, change their organisational structure or chose a non-engaged CPA strategy. This approach also assumes that at the same time those operating in more legitimate low-risk sectors would 
chose the engaged approach to CPA and generally would be more active in their non-market strategies than those who operate in targeted high risk areas.

Yet the puzzle arises. How can we explain that IB firms - even in the most hardly hit servicerelated sectors - actively engage in CPA and only a small minority choses the non-engaged approach or the more drastic choice of exit or restructuring?

Our study aims to explore these questions and investigate how MNE subsidiaries manage their CPA in a host country context, where political legitimacy of firms may change from one day to the next, depending on which sector they are operating in. Will firms that operate in so called 'bad' FDI industries manage a different CPA engagement strategy than those who operate in 'good' FDI sectors? Will those who operate in 'bad' FDI territory prefer to take a non-engaged approach to CPA and those operating in more legitimate sectors prefer to have an engaged approach to CPA? In the following sections we will answer these questions.

\section{DATA AND METHOD}

\subsection{Context}

The study focused on Hungary as a high-risk political context in the years of 2010-18. The researchers carried out an interview-based qualitative research combined with research on the political context and individual companies using secondary data. Hungary was selected as a revelatory case, because it is arguably one of the most extreme cases of a shift away from an emerging relatively liberal democratic regime after the fall of communism, towards a more authoritarian type of state and most extreme increase of political risk (Eisenhardt, 1989; Yin, 1984).

Since the 2010 elections, - when Viktor Orbán's conservative party Fidesz acquired a twothirds majority in the parliament - it has become increasingly clear that the "managerial" (Martin, 2002) aspect of the Hungarian brand of capitalism has lost ground to the "political" one, showing thus signs of a reversal of the power relations between the political and the economic elite. Since 2010, Hungary's "democracy score" has declined, bringing it closer to some of the less developed semi- 
consolidated democracies, like Romania and Bulgaria (Walker and Habdank-Kołaczkowska, 2012: 6). This new phase of transition is often referred to as "institutional backsliding" (Sallai and Schnyder, 2018). While Hungary was a front-runner in attracting FDI during the 1990s, since 2010, the country has at times engaged in an aggressive political rhetoric against foreign capital and adopted unfavourable policies such as high taxes in MNE dominated industries (Sass and Kalotay, 2012: 1). Hungary's rapid backsliding into a relational- state-dominated system, makes the country a critical case and hence particularly suitable to investigate the impact of institutional change on firm CPA strategies, because patterns become more visible than in less turbulent times (Flyvbjerg, 2006).

\subsection{Sample}

The data presented come from multiple rounds of data collection and a variety of sources, indepth interviews with business leaders, and experts from the context of the case, as well as documentary analysis of news reports over seven years. Data collection and data analysis was carried out in parallel, which allowed the development of theoretical insights and propositions, while testing and modifying these as the project evolved. Overlaps in data collection and analysis are beneficial, since it speeds up the analysis and "reveals helpful adjustments to data collection" (Eisenhardt, 1989, p. 535).

The empirical study comprised 56 semi-structured interviews. The interviews increased in focus and depth over the period due to the iterative and cumulative nature of the fieldwork process. To obtain multiple perspectives on the impacts of the new government on firms, the study sought a range of opinions as recommended for this type of research (Perry, 1998: 798). The sample included 43 business people, working at MNE subsidiaries from developed countries and local firms, and a further 13 experts from the context of the cases. By comparing and contrasting views from different actors, possible bias was decreased, and we interpreted the data in a more nuanced manner. In-depth interviews are an insightful method for exploring the "often nuanced causal factors of specific managerial action" (Lawton et al., 2013b, p. 231). Given the very sensitive nature of the topic of study and the political climate in Hungary, the sampling method necessarily was limited by companies' 
willingness to participate despite the possibility of political repercussions. While a self-selection bias cannot be completely excluded, given that an inductive, theory-building approach is used, the results are not affected by this shortcoming. Indeed, the sectoral composition of the sample is diverse: The single largest industry in our sample was banking and construction with six companies, followed by the manufacturing, energy, ICT and retail industries. Overall, the sample contains firms from eleven different industries. The interviewed subsidiaries originated from the US (6), France (4), Germany (3), UK (1), Switzerland (1), Denmark (1), Italy (1), and the Netherlands (1).

Interviewees comprised CEOs and Directors at MNE subsidiaries and at domestic Hungarian firms. We interviewed 23 respondents working at subsidiaries of MNEs in Hungary and a further 20 respondents from domestic firms. Due to the longitudinal nature of the study, we have interviewed in some cases the same respondents both in the early years of the Orbán regime in 2011-2013 as well as recently in 2015-17. Interviews were conducted in English and in Hungarian. Interviews in Hungarian were translated by one of the authors. Each interview lasted for about 60-90 minutes. Respondents were provided total confidentiality; all their data was coded and anonymized. Table 1 details the interviews, news articles and reports from which the qualitative data was drawn for this study.

Table 1: HERE

In order to reduce bias, we used secondary sources to increase our confidence about the reliability of the interview responses.

Table 2: HERE

We analysed over 70 pieces of printed and online newspaper articles and reports found on corporate websites, journalistic sources and publications by reputable NGOs such as Transparency International. Due to the lack of scholarly research on these topics in Hungary, such sources are often the only information available and are more reliable than official government sources. 


\section{FINDINGS}

\subsection{The Company Level: Subsidiaries' CPA strategies}

Based on the empirical analysis we identified five different CPA strategies that subsidiaries use in Hungary's high-risk context. See Table 3.

\section{TABLE 3: HERE}

Four out of the five depend on the type of engagement with the host government and the level of adaptation to the host country's public policy, whereas the fifth, the exit (Hirschman, 1970) strategy is outside of this framework, as in this category firms chose to either leave the host country or sell part or the whole of their subsidiary to the government. Figure 1 illustrates the CPA strategies used by MNE subsidiaries in a high-risk host country context.

\section{FIGURE 1: HERE}

In the context of high political risk, it is difficult for companies to develop coping or buffering strategies like the ones that Dieleman and Boddewyn (2012) describe, because in contrast to Suharto's Indonesia, the Hungarian public policy context is uncertain. However, instead of relying only on nonengaged CPA approaches by exercising 'no exit' and 'no voice' (De Villa et al., 2018:7) strategy as earlier studies suggested, findings of this study show that subsidiaries use a variety of different engaged and non-engaged methods to sustain their competitiveness in the host market. Instead of just staying within the high-risk host country context, without exerting influence over the host country's public policy - impacted by their host country legitimacy, size, compliance towards their MNE's regulatory framework and the nature of their activities (export vs. domestic) - firms engage in different CPA activities (see Table 4).

\section{TABLE 4: HERE}

Interviews suggest that the Orbán government's attack on 'bad FDI' and the consequent change in firms' legitimacy had an impact on firms' strategies and investment decisions - however, 
not necessarily as the researchers have expected. Literature suggest that when firms perceive high host country political risk - arising from host country political institutions and from the distance between home and host country political institutions - they will prefer a non-engaged approach to CPA (Villa et al., 2018). In contrast, our study shows, that most subsidiaries try to adapt to governmental pressures and decide to cooperate with the regime by engaging actively in public policy. The 'active responsiveness strategy' refers to the situation when firms respond to the host country's pressures by adapting to the government's public policy and engaging with the government hoping for better policy outcomes. Some of the political actions used within this approach belong to well-known information strategies identified by Hilmann and Hitt (1999) such as lobbying or writing policy papers. However, in the high-risk host country context subsidiaries are often required to extend these well-known, traditional CPA methods with other practices that open the doors directly to governmentlevel decision-makers as well as which substantiate their 'loyalty' towards the government's strategic objectives or more generally the governing elite.

Besides, signing a 'Strategic Partnership Agreement' with the government, which outlines the main framework of collaboration between the subsidiary and the government, firms also engage in several other types of CPA techniques, such as: joint public-private projects with the government, often with EU funding; investment projects with state support; the use of external PA consultancies that are often related to the government to get access to high level government officials; direct engagement with high-level decision-makers (often the prime minister) through the subsidiary's CEO or even the $\mathrm{CEO}$ of the regional headquarter or the main headquarter; as well as finding direct engagement through the parent company's embassy; or using suppliers that are 'recommended' by the government in their supply chains.

Although some of these actions are initiated by the subsidiaries, other are prompted by the state. Respondents, especially in less legitimate sectors that were more affected by state intervention expressed that fear and uncertainty often lead to servility and cooperation. 
"Yes, and I feel that in order to represent my company's interests I must be servile, but on the other hand this impacts my private life. I do not go to the street to protest that much anymore...I am more allowing." (Subsidiary7, 16.08.2016).

Many firms in Hungary choose not to 'argue' with the state, but rather try and please the government, so that they can get concessions or preferential treatment in return. They feel threatened by the state and fear retaliatory measures if they are not politically subservient.

The active responsiveness approach may also involve participation doing business through government-related oligarchs and their firms. Although subsidiaries rarely engage in corruptionrelated activities (and corruption was not part of the scope of this study), they might use governmentrelated or government referred suppliers to show their loyalty and strengthen their legitimacy towards the host country's government.

Although many firms both from the most and the least legitimate sectors engage in active responsiveness, some firms chose to refuse to openly cooperate with the government. We labelled this type of CPA strategy the 'passive responsiveness strategy', which has similarities with what De Villa et al., 2018 identified as 'low visibility' approach. Firms in this category avoid directly influencing the government and adopt a low public profile (De Villa et al., 2018). However, in contrast to the 'low visibility' approach, the 'passive responsiveness' strategy is an engaged strategy as companies attempt to influence public policy, however they choose collective representation channels - such as silent engagement through sectoral associations, and/or chambers of commerce, the avoidance of using the press and the avoidance of 'going alone', direct lobbying strategies. Companies in this category try to avoid direct cooperation or confrontation with the government by taking the 'wait and see' approach and trying to seek representation for their interests at interest groups. They put all investment decisions on hold, or channel investments to other countries in the region and keep costs at a minimum.

"There is no longer-term economic strategy. It is always changing, and we cannot plan. We feel that, because of the short-sightedness of politics, the government misses big opportunities, for example investments." (Respondent at Subsidiary11, interviewed on 06.09.2011.) 
As Hungary is an EU member state, subsidiaries could in principle turn to the EU's institutions to seek protection from the increasingly autocratic government's interventions. However, our interviews show that that is not the case. Subsidiaries that are members in industrial associations refrain from trying to use the EU level to alter the host country's institutional environment through lobbying the EU's authorities, because of corporate leaders' direct exposure to the autocratic state. Or with other words, subsidiaries tend to avoid confrontation with the host government through Brussels as this might have a negative impact on their legitimacy as viewed by the host government.

A respondent at a multinational's subsidiary - who is also a member at a host country association explained that they actively engage in a European umbrella organization in Brussels, however they intentionally do not formulate messages at EU level for fear of domestic repercussions:

"Truthfully, we do not let our voice be heard [in Brussels]. Whatever the leader of the Polish association says is good - they have a consolidated situation at home, and he can talk. We say nothing. ...It can cause troubles at home" (Respondent at Subsidiary8, interviewed on 16.04.2012.)

Hence, rather than voicing concerns in international arenas like the EU institutions, companies attempt to remain invisible to the government. Therefore, the strategy of this second group of companies consists in surviving the autocratic regime in a state of 'dormancy' to use a biological analogy.

This leads to the following proposition:

\section{Proposition 1: The more discontinuous risk firms face the more likely they will choose an engaged}

\section{CPA strategy in the form of active or passive responsiveness.}

In contrast to the passive responsiveness strategy, the 'non-responsiveness strategy' is chosen by firms that do not want to engage with public policy in any way but neither do adapt to the policy changes. The non-responsive strategy characterised the behaviour of those companies that were nonresponsive for a few years and then decided to implement the exit strategy. Hence the non-responsive strategy could be defined as the first step towards 'exit'. Within the sample, we identified three subsidiaries that were following the non-responsive strategy until they exited and in all three cases the 
government has changed the structure and conditions of the industries that the subsidiaries were operating in so drastically that these firms chose not to adapt to the requirements, as adapting would have meant that they have to operate long-term losses. In all three cases the decision of exit took years.

Despite the few 'exit' cases - although in the early years of the Orbán regime many multinationals have consider pulling out of the Hungarian market in the first few years (2010-2013) most of the interviewed companies decided to stay as they did not want to lose their established market shares. The 'capital flight' strategy described by some researchers (e.g. Markus 2012) does hence not seem to be widely used by companies in Hungary under the Orbán regime. Instead, rather than expanding and innovating, some firms chose to operate quietly with minimal investment, minimal engagement with the host government and minimal adaptation to the local conditions.

The fourth category is 'restructuring', which resonates with De Villa et al.'s 'reconfiguration' strategy (2018) or Dieleman and Boddewyn's 'buffering' strategy (2012) according to which firms initiate second-order changes within their organisational structure and processes in order to maintain competitiveness (De Villa et al., 2018) or to circumvent the regime's influence (Dieleman and Doddewyn, 2012). However, in contrast to the reconfiguration and buffering approaches, the 'restructuring' strategy may be defined as an 'engaged' CPA approach, which helps firms in less legitimate industries or industries under severe government intervention to modify, split up or rearrange the ownership of their subsidiary in order to 'save' the other parts of the firm.

This leads to the following proposition:

Proposition 2: The lower a firm's legitimacy in the eyes of the government, the more likely they will engage in a non-engaged strategy or restructuring.

Companies that follow this approach divide their operations into different business units, creating smaller sub-subsidiaries in fields where government appropriation is considered to have a higher chance. Restructuring could involve the rearrangement of ownership, organisational structure 
or the restructuring of business units according to different types of activities. In the sample one subsidiary had concrete contingency plans for 'restructuring'. The firm's respondent claimed that the subsidiary is in constant tension due to the fears of government nationalisation plans within the industry, but due to their large investment in Hungary they ruled the 'exit' option out. The company introduced a restructuring plan that would be implemented in case the government initiates nationalisation.

"That kind of structure could be something that could make it easier for us to adapt if the environment became really nasty. We have not decided to do that, it is one of the things we look at from time to time. We are not sure if this is one of the cures for the disease, but it is a factor that we take into consideration. You cannot really prepare for nationalisation. We are sure it is not going to be Venezuela or Argentina, but there are all kinds of ways to do that under the carpet."

Those firms that decided not to engage nor to adapt may 'exit' Hungary. This last strategy draws on Hirschman's (1970) exit strategy, implying that the MNE leaves or does not even enter the host country (Meyer et al., 2009). This type of non-engaged approach to CPA assumes that the MNE avoids operations in the host country and the firm exits as the senior management is unable or unwilling to invest in efforts to influence the host country's public policy (De Villa et al., 2018). However, we found that MNEs do not simply exit, but even within the exit option they may have a choice in a high-risk autocratic context. They either exit by leaving the country (Hirschman, 1970) and moving their operations into another country, or they exit by selling their subsidiary to the government. The current study found examples in both categories. Some companies decided to leave the country simply by pulling their operations out of Hungary, while others decided to make a profit on leaving by selling their operations to the government. Therefore, we define leaving the host country by closing subsidiary's operations 'Non-engaged exit', while selling off part of the business or the whole business to the government as 'Engaged exit'. Within the sample we found one company that left with non-engaged exit and two companies that left Hungary with engaged exit.

This leads to the following proposition: 
Proposition 3: When an MNE decides to exit a host market, the higher the level of the host country's intervention in the firm's sector, the more likely the MNE will be to choose an engaged exit.

\section{DISCUSSION \& CONCLUSION}

In this paper we explored how MNEs of foreign subsidiaries manage their political strategies in high-risk institutional contexts. We noted the discrepancy of our findings from the Hungarian context with recent studies on non-engagement in high-risk political contexts. Our empirical findings show that MNE subsidiaries use a wide range of non-engaged and engaged strategies to handle the increasingly politically risky environment. This extends previous studies that find that subsidiaries choose non-engagement strategies (de Villa et al., 2018) in high-risk context. We explain our findings by arguing that firms may chose different CPA engagement strategies in constantly high-risk environments and in environments where risk drastically increases after market entry. We investigated firms that have been operating in the Hungarian market for many years before their political environment has changed. We found that in the increased, discontinuous risk context, firms opt for both non-engaged, and engaged strategies in their political activities.

Our findings show the importance of the legitimacy perspective to FDI (Stevens et al., 2016) to understand these strategies in rapidly changing political environments. Firms appear to choose strategies that maximise their legitimacy based on their assessment of the government's goals. Legitimacy is hence a key driver explaining different strategic choices. Our study also suggest that the legitimacy perspective can be enhanced by considering the nature of risk that firms face. In contexts of continuous risk, firms may rely more on non-engaged strategies (De Villa et al., 2018), whereas in host countries, where risk could be defined as discontinuous subsidiaries engage in a combination of engaged and non-engaged political strategies.

\section{Practitioner implications}


The practitioner implications of our study are that even in a very hostile environment like Orbán's Hungary, many companies still seem to prefer to keep a presence in a temporarily unattractive environment, hoping for long-term pay-offs on their presence.

\section{Limitations}

The limitations of our study have to do with the case-study nature of the research and the possible self-selection bias in the sample. Indeed, given the sensitivity of the topic, we cannot exclude that a certain level of self-selection bias may have been introduced. The variety of companies we interviewed and the variety of answers that we obtained, however, indicated that this is not a major issue. Future studies should attempt to compare our findings to other cases of 'clan states' as well as extending the sample to a larger number of firms. Future research also should investigate whether the CPA strategies adopted in a context of high arbitrariness and uncertainty still lead to positive performance outcomes and are hence viable in the long-term. 


\section{REFERENCES}

Ágh, A., 2016 The Decline of Democracy in East-Central Europe, Problems of Post-Communism, 63:56, 277-287, DOI: $\underline{10.1080 / 10758216.2015 .1113383}$

Bitektine A. 2011. Toward a theory of social judgements of organization: the case of legitimacy, reputation, and status. Academy of Management Review, 36:1, 151-179

Boddewyn, J. 2005. Early US business-school literature (1960-1975) on international businessgovernment relations: its twenty-first century relevance, in (ed. Grosse R.). International Business-Government Relations in the $21^{\text {st }}$ Century. New York: Cambridge University Press, $25-48$

Boddewyn, J., Brewer T., 1994. International business political behaviour: new theoretical directions. Academy of Management Review, 19: 1, 119-143

Bohle, D. and Greskovits, B. 2012, Capitalist Diversity on Europe's Periphery, Ithaca: Cornell University Press

Bohle, D. 2018, European Integration, Capitalist Diversity and Crises Trajectories on Europe's Eastern Periphery, New Political Economy, 23:2, 239-253, DOI: 10.1080/13563467.2017.1370448

Brewer, T. L., 1992. An issue-area approach to the analysis of MNE-government relations. Journal of International Business Studies, 23, 295-309

Byrne, A., Hungary to offer EU's lowest corporate tax rate, Financial Times, accessed 14 January, 2019, from https://www.ft.com/content/302fa4b4-acda-11e6-9cb3-bb8207902122

Cuervo-Cazurra, A., 2008. Better the devil you don't know: Types of corruption and FDI in transition economies. Journal of International Management 14, 12-27., https://doi.org/10.1016/j.intman.2007.02.003

Bremmer, I. 2014, The new rules of globalization. Harvard Business Review, 92(1), 103-107 
Darendeli, S. I. \& Hill, T. Journal of International Business Studies, 2016 47: 68. https://doi.org/10.1057/jibs.2015.27

De Villa M. A., Rajwani T., Lawton, T. 2018. To engage or not to engage with host governments: Corporate political activity and host country political risk, Global Strategy Journal, 2018, 1-35

Delios, A. and Henisz, W., 2003, Political hazards, experience, and sequential entry strategies: the international expansion of Japanese firms, 1980-1998, Strategic Management Journal, 43, 305 323

Dieleman, M. \& Boddewyn, J. J. 2012. Using Organization Structure to Buffer Political Ties in Emerging Markets: A Case Study. Organization Studies, 33, 71-95.

EBRD 2005. Transition report 2005: Business in transition. London: European Bank for Reconstruction and Development

Eisenhardt, K. M. 1989. Building Theories from Case Study Research. Academy of Management Review, 14, 532-550.

Greskovits, B. 2015, The Hollowing and Backsliding of Democracy in East Central Europe. Glob Policy, 6: 28-37. doi:10.1111/1758-5899.12225

Getz, K. A., \& Oetzel, J. M. (2009). MNE strategic intervention in violent conflict: Variations based on conflict characteristics. Journal of Business Ethics, 89(SUPPL. 4), 375-386. https://doi.org/10.1007/s10551-010-0412-6

Han, X., Liu X., Gao L., Ghauri, P., 2018. "Chinese Multinational Enterprises in Europe and Africa: How do They Perceive Political Risk?," Management International Review, Springer, vol. 58(1), pages 121-146, February.

Henisz, W.J., Zelner, B.A., 2005, Legitimacy, interest group pressures, and change in emergent institutions: The case of foreign investors and host country governments, Academy of Management Review 30 (2), 361-382 
Hillman, A.J., Hitt, M.A., 1999. Corporate Political Strategy Formulation: A Model of Approach, Participation, and Strategy. Academy of Management Review 24, 825-842.

Hillman, A.J., Wan, W.P., 2005. The determinants of MNE subsidiaries' political strategies: evidence of institutional duality. Journal of International Business Studies, 36, 322-340. doi:10.1057/palgrave.jibs. 8400137

Hirschman, A. O., 1970. Exit, voice, and loyalty: Responses to decline in firms, organizations, and states. Cambridge, MA: Harvard University Press.

Jiang, Y., Peng, M.W., Yang, X., Mutlu, C.C., 2015. Privatization, governance, and survival: MNE investments in private participation projects in emerging economies. Journal of World Business. 50, 294-301. doi:10.1016/j.jwb.2014.10.006

John. A., Lawton. C. T., 2018, International Political Risk Management: Perspectives, Approaches and Emerging Agendas, International Journal of Management Reviews, 20, 847-879

Kolstad, I., Villanger, E., 2008, Determinants of foreign direct investment in services, European Journal of Political Economy, 24: 2, 518-533

Kornai, J. 2012. Centralisation and the Capitalist Market Economy in Hungary. CESifo Forum, 13, 4759.

Kostova, T., Roth, K., 2002. Adoption of an organizational practice by subsidiaries of multinational corporations: Institutional and relational effects. Academy of Management Journal. 45, 215-233. doi: $10.2307 / 3069293$

Kostova, T., Zaheer, S., 1999. Organizational Legitimacy under Conditions of Complexity: The Case of the Multinational Enterprise. Academy of Management Review, 24, 64-81., https://www.jstor.org/stable/259037 
Lawton, T., Rajwani, T. \& Doh, J. 2013. The antecedents of political capabilities: A study of ownership, cross-border activity and organization at legacy of airlines in a deregulatory context. International Business Review, 22, 228-242.

Lu, J. Liu, X., Wright, M., Filatotchev, I. 2014. International experience and FDI location choices of Chinese firms: the moderating effects of home country government support and host country institutions. Journal of International Business Studies, 45, 428-449

Markus, S. 2012. Secure Property as a Bottom-up Process. Firms, Stakeholders, and Predators in Weak States. World Politics, 64, 242-277

Martin, R. 2013. Construction Capitalisms. Transforming Business Systems in Central and Eastern Europe, Oxford, Oxford University Press.

Martin, R. 2002. Politicized Managerial Capitalism: Enterprise structures in post-socialist Central and Eastern Europe. Journal of Management Studies, 39.

Marquis, C., Qian, C., 2014. Corporate Social Responsibility reporting in China: symbol or substance? Organization Science, 25:1, 127-148

Meznar, M. B., Nigh, D. 1995. Buffer or Bridge? Environmental and organizational determinants of public affairs activities in Ameriacan firms. Academy of Management Journal, 38, 975-996

Meyer, K. E., Estrin, S. , Bhaumik, S. K. and Peng, M. W. 2009, Institutions, resources, and entry strategies in emerging economies. Strategic Management Journal. 30: 61-80. doi:10.1002/smj.720

Nell, P.C., Puck, J., Heidenreich, S., 2015. Strictly limited choice or agency? Institutional duality, legitimacy, and subsidiaries' political strategies. Journal of World Business, 50, 302-311.

Mutlu, C.C., Zhan, W., Peng, M.W., Lin, Z.J., 2015. Competing in (and out of) transition economies. Asia Pacific Journal of Management. 32, 571-596. doi:10.1007/s10490-015-9419-y 
Nölke, A. \& Vliegenthart, A. 2009. Enlarging the Varieties of Capitalism. The Emergence of Dependent Market Economies in East Central Europe. World Politics, 61, 670-702.

Oetzel, J.M., Oh, C.H., 2014. Learning to Carry the Cat by the Tail: Firm Experience, Disasters, and Multinational Subsidiary Entry and Expansion. Organization Science, 25, 732-756. https://doi.org/10.1287/orsc.2013.0860

Oetzel, J. M., \& Miklian, J. 2017. Multinational enterprises, risk management, and the business and economics of peace. Multinational Business Review, 25(4), 270-286. https://doi.org/10.1108/MBR-09-2017-0064

Oh, C. H. and Oetzel, J. 2011, Multinationals' response to major disasters: how does subsidiary investment vary in response to the type of disaster and the quality of country governance? Strategic Management Journal, 32: 658-681. doi:10.1002/smj.904

Oh, C. H. and Oetzel, J. 2017. Once bitten twice shy? Experience managing violent conflict risk and MNC subsidiary-level investment and expansion. Strategic Management Journal, 38: 714-731. doi:10.1002/smj.2498

Oliver, C. \& Holzinger, I. 2008. The effectiveness of strategic political management: A dynamic capabilities framework. Academy of Management Review, 33, 495-520.

Orenstein, M. A. 2013. Reassessing the neo-liberal development model in Central and Eastern Europe. In: SCHMIDT, V. \& THATCHER, M. (eds.) Resilient Liberalism in Europe's Political Economy. Cambridge: Cambridge University Press.

Perry, C. 1998. Processes of a case study methodology for postgraduate research in marketing. European Journal of Marketing, 32, 785-802.

Sallai, D. 2013. European Union Lobbying and the Golden Cage of Post-Socialist Network Capitalism in Hungary. Journal of Common Market Studies, 51, 948-964

Sallai, D, Schnyder, G., 2015. Strong State, Weak Managers: How Firms Cope with Autocracy in Hungary, Working Papers wp474, Centre for Business Research, University of Cambridge 
Sallai, D., Schnyder, G., The Transformation of Post-Socialist Capitalism - From Developmental State to Clan State? (January 12, 2018). Greenwich Paper in Political Economy No. GPERC57. Available at $\quad$ SSRN: https://ssrn.com/abstract=3100775 or http://dx.doi.org/10.2139/ssrn.3100775

Sass, M. 2017. Latecomers May Be Admitted: Foreign Direct Investment Between the CEE Countries Latecomers May Be Admitted: Foreign Direct Investment Between the CEE Countries, in Balázs Szent-Iványi (ed), Foreign Direct Investment in Central and Eastern Europe: Post-crisis Perspectives. Palgrave Macmillan, ISBN: 978-3-319-40495-0

Sass, Magdolna \& Kalotay, Kalman. (2012). Hungarian inward FDI and its policy context. Columbia FDI Profiles.

Spar, D. L. 2001. National policies and domestic politics. In Rugman, A. M. and Brewer T. L. (eds), The Oxford Handbook of International Business. Oxford: Oxford University Press, 206-231

Stevens, C. E., Xie, E. and Peng, M. W. (2016), Toward a legitimacy-based view of political risk: The case of Google and Yahoo in China, Strategic Management Journal, 37, 945-963

Yin, R. 2003. Case study research: Design and methods. Thousand Oaks: Sage.

Walker, C. \& Habdank-Kolaczkowska, S. 2012. Nations in Transit - Fragile frontier: Democracies growing vulnerability in Central and Southeastern Europe. Freedomhouse, available at: https://www.freedomhouse.org/sites/default/files/Release\%20Booklet.pdf. 


\section{TABLES}

TABLE 1: SOURCES USED

\begin{tabular}{|l|l|}
\hline Period of interview & Number of interviews \\
\hline $2015-2017$ & 24 \\
\hline $2011-2013$ & 32 \\
\hline Total number of interviews & 56 \\
\hline Total number of printed and online news articles and reports & 71 \\
\hline
\end{tabular}

TABLE 2: INFORMANTS BY SECTOR AND TYPE

\begin{tabular}{|c|c|c|c|}
\hline Informant's sector & $\begin{array}{l}\text { Type of interviewee (number of } \\
\text { interviews) }\end{array}$ & $\begin{array}{l}\text { Year of interviews (number of } \\
\text { interviews in that year) }\end{array}$ & $\begin{array}{l}\text { Number of Total } \\
\text { interviews in the } \\
\text { sector }\end{array}$ \\
\hline Banking & CEO (4), Vice-CEO (2) & $2012(4), 2016(2)$ & 6 \\
\hline Construction & Chair (2), Director (2), CEO (1) & $2011(3), 2012(1), 2016(1)$ & 5 \\
\hline Energy & CEO(1), Director (5) & $2011(4), 2013(1), 2015(1)$ & 6 \\
\hline ICT & CEO (4), Director (3) & $\begin{array}{l}2011(3), 2012 \text { (1), } 2016 \text { (1), } \\
2017 \text { (2) }\end{array}$ & 7 \\
\hline Manufacturing & $\begin{array}{l}\text { CEO (5), Vice-CEO (1), Director } \\
\text { (1) }\end{array}$ & $\begin{array}{l}2011(2), 2012(1), 2015 \text { (1), } \\
2016 \text { (2), } 2017(1)\end{array}$ & 7 \\
\hline Telecommunication & CEO (1), Vice-CEO (1) & $2015(1), 2016(1)$ & 2 \\
\hline Retail & Director (4) & $2011(1), 2012(1), 2016(2)$ & 4 \\
\hline Wholesale & CEO (2) & $2012(1), 2017(1)$ & 2 \\
\hline
\end{tabular}




\begin{tabular}{|c|c|c|c|}
\hline $\begin{array}{l}\text { All other sectors: } \\
\text { tobacco, tourism, } \\
\text { consulting, } \\
\text { advertising, } \\
\text { beverages }\end{array}$ & CEO (1), Director (3) & $\begin{array}{l}2012(1), 2013 \text { (1), } 2016 \text { (1), } \\
2017 \text { (1) }\end{array}$ & 4 \\
\hline Other & $\begin{array}{l}\text { Secretary General (4), Director } \\
\text { (7), Journalist (1), Political advisor } \\
\text { (1) }\end{array}$ & $\begin{array}{l}2011 \text { (4), } 2012 \text { (2), } 2016 \text { (2), } \\
2017 \text { (3), } 2011 \text { ( 1), } 2017 \text { (1) }\end{array}$ & 13 \\
\hline $\begin{array}{l}\text { Total number of } \\
\text { interviews }\end{array}$ & $\begin{array}{l}\text { Respondents at MNE subsidiaries } \\
\text { (22), Domestic firms (21), NGOs } \\
\text { and other (13) }\end{array}$ & $\begin{array}{l}2011(18), 2012 \text { (12), } 2013(2), \\
2015(3), 2016(12), 2017(9)\end{array}$ & 56 \\
\hline
\end{tabular}


TABLE 3: Taxonomy of the political strategies that MNE subsidiaries use to stay in high political risk host markets

\begin{tabular}{|c|c|c|c|c|c|}
\hline & $\begin{array}{l}\text { Active } \\
\text { Responsiveness } \\
\text { Strategy }\end{array}$ & $\begin{array}{l}\text { Passive } \\
\text { Responsiveness } \\
\text { (Dormancy) }\end{array}$ & $\begin{array}{l}\text { Non- } \\
\text { responsiveness }\end{array}$ & Restructuring & Exit \\
\hline Definition & $\begin{array}{l}\text { An 'engaged' } \\
\text { approach to CPA: } \\
\text { Active adaptation } \\
\text { to the } \\
\text { government's } \\
\text { public policy and } \\
\text { engaging with the } \\
\text { government } \\
\text { hoping for better } \\
\text { policy outcomes }\end{array}$ & $\begin{array}{l}\text { An 'engaged' } \\
\text { approach to } \\
\text { CPA: } \\
\text { Engaged } \\
\text { strategy by } \\
\text { attempting to } \\
\text { influence public } \\
\text { policy, through } \\
\text { collective } \\
\text { representation } \\
\text { channels }\end{array}$ & $\begin{array}{l}\text { Non-engaged } \\
\text { approach to CPA: } \\
\text { No engagement } \\
\text { with public policy } \\
\text { in any way and no } \\
\text { adaptation either }\end{array}$ & $\begin{array}{l}\text { An 'engaged' } \\
\text { approach to CPA: } \\
\text { Rearrangement of: } \\
\text { - ownership, } \\
\text { - organisational } \\
\text { structure o } \\
\text { the } \\
\text { restructuring } \\
\text { of business } \\
\text { units } \\
\text { according to } \\
\text { different } \\
\text { types } \\
\text { activities } \\
\text { in order to 'save' } \\
\text { the other parts of } \\
\text { the firm }\end{array}$ & $\begin{array}{l}\text { Leaving the } \\
\text { country by } \\
\text { Engaged exit: } \\
\text { selling the } \\
\text { whole or part of } \\
\text { the company to } \\
\text { the state or } \\
\text { people close to } \\
\text { the governing } \\
\text { elite } \\
\text { Non-engaged } \\
\text { exit: leaving the } \\
\text { country }\end{array}$ \\
\hline Actions & $\begin{array}{ll}\text { - } & \text { Strategic } \\
\text { Partnership } \\
\text { Agreement } \\
\text { with } \\
\text { Government, } \\
\text { - } & \text { Lobbying } \\
\text { - } & \text { Writing } \\
\text { policy papers } \\
\text { - } & \text { Contracting } \\
\text { government- } \\
\text { friendly } \\
\text { consulting } \\
\text { firms } \\
\text { Contracting } \\
\text { government } \\
\text { recommended } \\
\text { suppliers }\end{array}$ & $\begin{array}{l}\text { - Avoidance } \\
\text { of using the } \\
\text { press } \\
\text { - Avoidance } \\
\text { of 'going } \\
\text { alone' } \\
\text { - Avoidance } \\
\text { of direct } \\
\text { lobbying } \\
\text { strategies } \\
\text { - Investment } \\
\text { decisions } \\
\text { on hold }\end{array}$ & 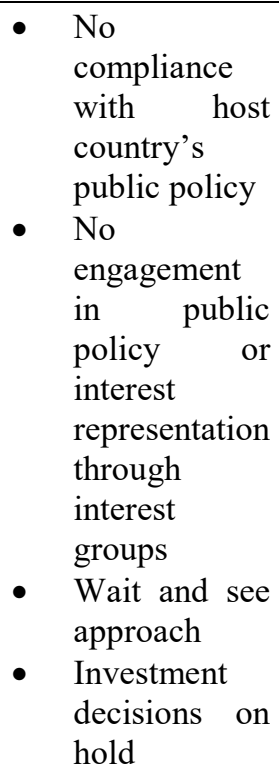 & $\begin{array}{l}\text { - } \begin{array}{l}\text { Split up or } \\
\text { rearrange the } \\
\text { ownership, }\end{array} \\
\text { - } \begin{array}{l}\text { Rearrange } \\
\text { org. structure }\end{array} \\
\text { - } \\
\text { Restructure } \\
\text { business units }\end{array}$ & 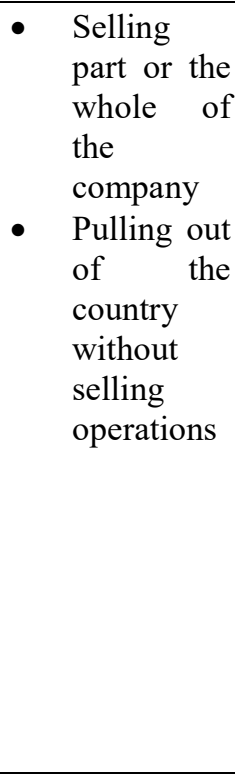 \\
\hline
\end{tabular}


TABLE 4: CPA STRATEGIES AND ACTIONS IN HIGH RISK CONTEXT

\begin{tabular}{|c|c|c|c|c|}
\hline CPA Strategy & Definition & Quote Examples & Actions & $\begin{array}{l}\text { Company } \\
\text { examples }\end{array}$ \\
\hline $\begin{array}{l}\text { Active } \\
\text { responsiveness }\end{array}$ & $\begin{array}{l}\text { Engage with } \\
\text { the host } \\
\text { government } \\
\text { and adapt to } \\
\text { its public } \\
\text { policy }\end{array}$ & $\begin{array}{l}\text { "There is a regular, very high-level } \\
\text { relationship between us and the } \\
\text { government, where behind closed } \\
\text { doors we get very reassuring } \\
\text { signals". (Subsidiary7) } \\
\text { "As we are so exposed to the state it } \\
\text { is expected that the top managers } \\
\text { represent us towards government } \\
\text { decision-makers." (Subsidiary2) } \\
\text { "Go there [government] personally, } \\
\text { get some support from the embassy, } \\
\text { go there [government] as part of the } \\
\text { chamber, we also have our opinions } \\
\text { that we publish, and we should speak } \\
\text { to each other and think } \\
\text { constructively. "(Subsidiary2) }\end{array}$ & 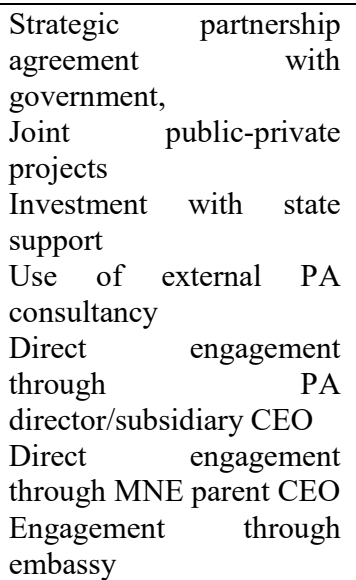 & $\begin{array}{l}\text { Subsidiary } 1,2, \\
4,6,7,10,12, \\
15,16,17,18\end{array}$ \\
\hline $\begin{array}{l}\text { Passive } \\
\text { responsiveness }\end{array}$ & $\begin{array}{l}\text { Adapt to the } \\
\text { host country's } \\
\text { public policy } \\
\text { but do not } \\
\text { engage with } \\
\text { the } \\
\text { government } \\
\text { directly }\end{array}$ & $\begin{array}{l}\text { "Truthfully, we do not let our voice } \\
\text { be heard. Whatever the leader of the } \\
\text { Polish association says is good - they } \\
\text { have a consolidated situation at } \\
\text { home, and he can talk. We say } \\
\text { nothing." (Subsidiary8) }\end{array}$ & $\begin{array}{l}\text { Silent engagement only } \\
\text { through sectoral } \\
\begin{array}{l}\text { association and/or } \\
\text { chamber or commerce }\end{array} \\
\begin{array}{l}\text { Compliance with public } \\
\text { policy }\end{array} \\
\begin{array}{l}\text { Avoidance of press or any } \\
\text { other voice strategy }\end{array}\end{array}$ & $\begin{array}{l}\text { Subsidiary } 3,5 \text {, } \\
8\end{array}$ \\
\hline $\begin{array}{l}\text { Non- } \\
\text { responsiveness } \\
\text { (can be first phase } \\
\text { of exit) }\end{array}$ & $\begin{array}{l}\text { Do not engage } \\
\text { with } \\
\text { government, } \\
\text { do not adapt to } \\
\text { public policy }\end{array}$ & $\begin{array}{l}\text { "There is no longer-term economic } \\
\text { strategy. It is always changing, and } \\
\text { we cannot plan. We feel that, } \\
\text { because of the short-sightedness of } \\
\text { politics, the government misses big } \\
\text { opportunities, for example } \\
\text { investments." (Subsidiary11) } \\
\text { Most companies had to get used to } \\
\text { the new reality and you try to stay } \\
\text { out of trouble, out of the way, try to } \\
\text { keep your head low. In a word that is } \\
\text { really what you are trying to do. } \\
\text { Which for a size of company like us } \\
\text { it is extremely tough (Subsidiary1). }\end{array}$ & $\begin{array}{l}\text { No engagement with } \\
\text { public policy in any form } \\
\text { No adaptation to public } \\
\text { policy }\end{array}$ & Subsidiary 11 \\
\hline Restructuring & $\begin{array}{l}\text { Modify or } \\
\text { plan to modify } \\
\text { organisational } \\
\text { structure to } \\
\text { avoid } \\
\text { appropriation }\end{array}$ & $\begin{array}{l}\text { "There is a strategic trend in my } \\
\text { industry actually to separate [the } \\
\text { two] sides of the business [...] to } \\
\text { actually split it into two separate } \\
\text { companies. And there is talk that if } \\
\text { you do that then [...] part of the } \\
\text { business could be shared, you can } \\
\text { have the government taking a share } \\
\text { in that. } \\
\text { This is called functional separation } \\
\text { [...], utility companies have done } \\
\text { this for a while. That kind of } \\
\text { structure could be something that } \\
\text { could make it easier for us to adapt } \\
\text { if the environment became really } \\
\text { nasty" (Subsidiary1). }\end{array}$ & $\begin{array}{l}\text { Restructuring ownership } \\
\text { Restructuring } \\
\text { organisational structure } \\
\text { Restructuring business } \\
\text { units according to } \\
\text { activities in order to avoid } \\
\text { expropriation }\end{array}$ & Subsidiary 1 \\
\hline $\begin{array}{l}\text { Exit (Hirschma } \\
\text { 1970) }\end{array}$ & & & & \\
\hline
\end{tabular}




\begin{tabular}{|l|l|l|l|l|}
\hline Engaged Exit & $\begin{array}{l}\text { Selling off to } \\
\text { the state and } \\
\text { becoming a } \\
\text { state-owned } \\
\text { enterprise }\end{array}$ & $\begin{array}{l}\text { Selling off part of the } \\
\text { business or the whole } \\
\text { business }\end{array}$ & $\begin{array}{l}\text { Subsidiary 11, } \\
13,9\end{array}$ \\
Non-engaged Exit & $\begin{array}{l}\text { Closing } \\
\text { operations and } \\
\text { leaving the } \\
\text { country }\end{array}$ & $\begin{array}{l}\text { Leaving the host country } \\
\text { by closing subsidiary's } \\
\text { operations }\end{array}$ & Subsidiary 9 \\
\hline
\end{tabular}

Figures

Figure 1: CPA strategies used by MNE subsidiaries in a high-risk context

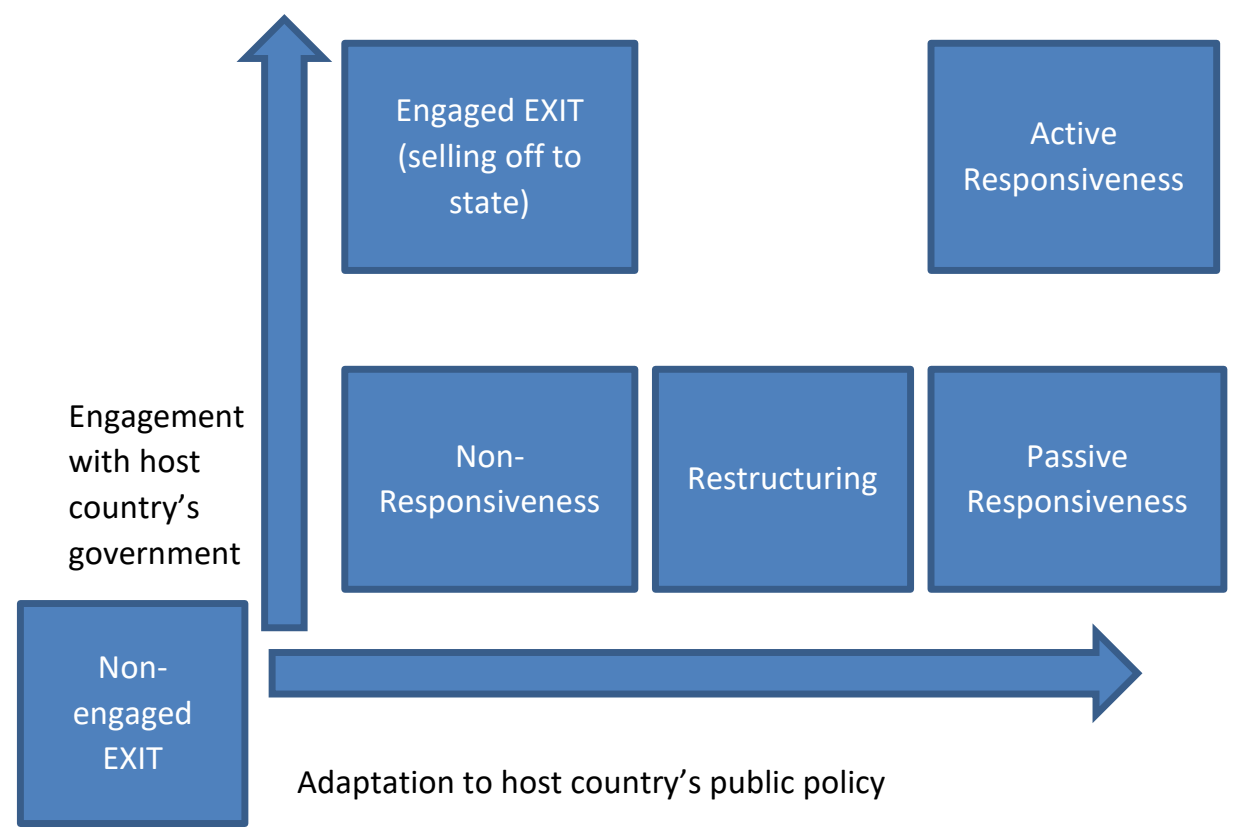

